\title{
PENINGKATAN HASIL BELAJAR MATEMATIKA MELALUI PENERAPAN MODEL PEMBELAJARAN DISCOVERY LEARNING BERBANTUAN LKPD
}

\author{
NILA SARI LATIF \\ UPTD Satuan Pendidikan SMPN 9 Marusu, Jl. Pattene No 119 A, Kabupaten Maros; \\ nilasari.82@gmail.com
}

\begin{abstract}
Abstrak. Tujuan dari penelitian ini adalah untuk mengetahui peningkatan hasil belajar matematika peserta didik kelas VIII A UPTD Satuan Pendidikan SMPN 9 Marusu melalui model pembelajaran discovery learning berbantuan LKPD. Subjek penelitian ini adalah peserta didik kelas VIII A UPTD Satuan Pendidikan SMPN 9 Marusu tahun ajaran 2018/2019 yang berjumlah 26 orang. Penelitian ini adalah penelitian tindakan kelas yang dilaksanakan dalam dua siklus dan melalui beberapa tahap dalam setiap siklusnya, yaitu perencanan, pelaksanaan tindakan, observasi dan evaluasi serta refleksi. Teknik pengumpulan data yang digunakan adalah tes hasil belajar peserta didik yang dilakukan tiap akhir siklus, observasi, refleksi, dokumentasi dan tanggapan peserta didik. Data yang terkumpul dianalisis dengan menggunakan analisis kuantitatif dan kualitatif. Hasil yang dicapai setelah pembelajaran dengan menggunakan model pembelajaran discovery learning berbantuan LKPD yaitu: (1) pada siklus I diperoleh skor rata-rata hasil belajar matematika peserta didik sebesar 61,92 mengalami peningkatan pada siklus II menjadi 75,38, standar deviasi pada siklus I 12,66 menjadi 9,48 pada siklus II dari skor ideal 100, (2) Terjadinya peningkatan frekuensi aktivitas peserta didik dan sikap peserta didik. Dari hasil penelitian di atas, maka dapat disimpulkan bahwa terjadi peningkatan hasil belajar matematika peserta didik kelas VIII A UPTD Satuan Pendidikan SMPN 9 Marusu melalui penerapan model pembelajaran discovery learning berbantuan LKPD.
\end{abstract}

Kata Kunci: Hasil Belajar Matematika, Discovery Learning, LKPD

\section{Improving Mathematics Learning Achievement by Applying Discovery Learning Models using LKPD}

\begin{abstract}
This study aims to identify the improvement in mathematics learning achievement for students of grade VIII A at SMPN 9 Marusu by applying discovery learning models using LKPD. Subjects of this study were 26 students of grade VIII A SMPN 9 Marusu academic year of 2018/2019. This study is a classroom action research conducted in two cycles in which consisting of several stages, namely planning, implementation, observation and evaluation as well as reflection. Data collection method applied were students' learning achievement test conducted at the end of each cycle, observation, reflection, documentation and student responses. The collected data were analyzed using quantitative and qualitative method. The achievement achieved after the discovery learning models using LKPD was applied are: (1) in cycle I, the average score of mathematics learning achievement of students is 61.92 increasing to 75.38 in cycle II. The deviation standard in the first cycle is 12.66 and increasing to 9.48 in the second cycle of the ideal score 100, (2) There is an increase in the frequency of student activities and student attitudes. Based on the above research achievement, it
\end{abstract}


can be concluded that there is an increase in mathematics learning achievement for students of grade VIII A at SMPN 9 Marusu by applying discovery learning models using LKPD.

Keywords. Mathematics Learning Achievement, Discovery Learning, LKPD

\section{Pendahuluan}

Pandangan peserta didik mengenai matematika yang dianggap ilmu abstrak dan penuh teori adalah pelajaran yang sangat sulit dan membosankan. Untuk mengubah persepsi peserta didik tentang matematika diperlukan keterampilan pengajaran yang mampu menarik minat belajar matematika peserta didik sehingga dapat belajar dengan keinginannya sendiri. Oleh karena itu, dibutuhkan suatu model pembelajaran dalam pembelajaran matematika agar peserta didik senang belajar matematika sehingga lebih mudah memahami ilmu matematika yang diajarkan.

Paradigma baru pendidikan matematika lebih menekankan pada peserta didik sebagai manusia yang memiliki potensi untuk belajar dan berkembang. Peserta didik harus aktif dalam pencarian dan pengembangan pengetahuan karena kebenaran ilmu tidak terbatas pada apa yang disampaikan oleh guru. Di samping itu guru harus menambah perannya menjadi fasilitator yang dapat membimbing peserta didik ke arah pembentukan pengetahuan yang bersumber dari diri mereka sendiri. Melalui paradigma baru tersebut diharapkan di kelas peserta didik aktif dalam belajar, aktif berdiskusi, berani menyampaikan gagasan dan menerima gagasan dari orang lain, dan memiliki kepercayaan diri yang tinggi. Dalam paradigma ini peserta didik diperbolehkan menggunakan usahanya sendiri dalam menyelesaikan suatu masalah matematika, bahkan dapat mengonstruksi pemahamannya dengan menggunakan bahasa dan lambangnya sendiri.

Realitas menunjukkan bahwa pelajaran matematika memiliki kesulitan tersendiri yang dihadapi oleh peserta didik. Salah satu fakta yang ditemukan bahwa di UPTD Satuan Pendidikan SMPN 9 Marusu Kabupaten Maros terkhusus di kelas VIII A pada umumnya peserta didik menganggap bahwa mata pelajaran matematika menjadi mata pelajaran yang kurang disenangi, hal ini berdasar pada wawancara tidak langsung dengan beberapa peserta didik di sekolah tersebut yang mengemukakan bahwa mereka tidak menyenangi matematika karena beberapa faktor diantaranya adalah mereka merasa kesulitan untuk memahami konsep dan simbol-simbol bahkan mereka cenderung lupa untuk mengingat kembali rumus yang telah diajarkan. Hal ini mengakibatkan peserta didik kesulitan untuk menyelesaikan soal-soal matematika yang berimbas pada perolehan hasil belajar matematika yang kurang maksimal. Sementara itu penguasaan matematika harus didasarkan pada pola berpikir, pengorganisasian dan pembuktian. Johnson dan Rising (1972) mengemukakan bahwa matematika adalah pola berpikir, pola mengorganisasikan, pembuktian yang logik, matematika itu adalah bahasa yang menggunakan istilah yang didefinisikan dengan cermat, jelas, dan akurat, representasinya dengan simbol dan padat, lebih berupa bahasa simbol mengenai ide daripada mengenai bunyi.

Sebagai tenaga pengajar/guru yang secara langsung terlibat dalam proses belajar mengajar, maka guru memegang peranan penting dalam menentukan peningkatan kualitas pembelajaran dan prestasi belajar yang akan dicapai peserta didiknya. Salah satu kemampuan yang 
diharapkan dikuasai oleh pendidikan dalam hal ini adalah bagaimana mengajarkan matematika dengan baik agar tujuan pembelajaran dapat dicapai semaksimal mungkin. Penguasaan materi dan cara pemilihan model pembelajaran yang sesuai dapat menentukan tercapainya tujuan pengajaran.

Salah satu model pembelajaran yang direkomendasikan oleh kurikulum 2013 saat ini adalah pembelajaran penemuan (discovery learning) yang bertujuan membantu peserta didik untuk dapat meningkatkan motivasi dan minat serta mampu memahami konsep dengan lebih baik sehingga peserta didik menjadi pembelajar yang mandiri. Hal ini juga diungkapkan oleh Harmin \& Toth (2012) bahwa salah satu cara paling baik untuk menginspirasi pembelajaran aktif adalah dengan menyertakan kebingungan, rasa penasaran, dan kebutuhan manusia untuk mengetahui ada apa dibalik segala hal. Dan kita dapat memfasilitasi elemen-elemen ini dengan kegiatan belajar bertipe penemuan. Guru bukan lagi sebagai sumber informasi terbanyak bagi peserta didik, tetapi guru membantu peserta didik dalam menyimpulkan informasi dari berbagai sumber dan mendorong peserta didik dalam pertukaran ide secara bebas.

Tokoh pendidikan yang pertama kali memperkenalkan metode penemuan (discovery) adalah Bruner (Takdir, 2012). Bruner meyakini bahwa implikasi discovery dalam proses pembelajaran akan mampu memberikan jaminan ideal bagi kematangan anak didik dalam mengikuti materi pelajaran, sehingga pada perkembangan selanjutnya dapat memperkuat wacana intelektual mereka. Metode ini merupakan suatu cara untuk mengembangkan cara belajar siswa aktif. Dengan menemukannya sendiri, menyelidiki sendiri, maka hasil yang diperoleh akan setia dan tahan lama dalam ingatan, sehingga tidak mudah dilupakan oleh siswa. Pengertian yang ditemukan sendiri merupakan pengertian yang betul-betul dikuasai dan mudah digunakan atau ditransfer dalam situasi lain. Dengan metode penemuan ini juga, anak belajar berpikir analisis dan mencoba memecahkan problema yang dihadapi sendiri, sehingga kebiasaan ini akan ditransfer dalam kehidupan bermasyarakat.

Discovery learning merupakan komponen dari praktik pendidikan yang meliputi model pembelajaran yang memajukan cara belajar aktif, berorientasi pada proses, mengarahkan sendiri, mencari sendiri, dan reflektif. Dalam proses belajar, peserta didik menemukan sendiri sesuatu hal yang baru, namun tidak berarti hal yang ditemukannya ini benar-benar baru sebab sudah diketahui oleh orang lain. peserta didik yang belajar dari pengalamannya melalui penemuan (discovery) lebih baik daripada hanya berbicara dan tidak pernah berbuat sama sekali. Ada beberapa prosedur yang harus dilaksanakan oleh guru dalam mengimplementasikan model pembelajaran discovery learning di kelas, seperti yang dikemukakan oleh Syah (2004) bahwa beberapa prosedur yang harus dilaksanakan dalam kegiatan belajar mengajar secara umum sebagai berikut: (1) Stimulation (stimulasi/pemberian rangsangan), (2) Problem statement (pernyataan/identifikasi masalah), (3) Data collection (pengumpulan data), (4) Data processing (pengolahan data), (5) Verification (pembuktian), dan (6) Generalization (menarik kesimpulan/generalisasi).

Guru dapat memaksimalkan model pembelajaran discovery learning yang diterapkan dikelas dengan bantuan Lembar Kerja Peserta Didik (LKPD). Wulandari (2013) menyatakan bahwa peran LKPD sangat besar dalam proses pembelajaran karena dapat meningkatkan aktivitas peserta didik dalam belajar dan penggunaannya dalam pembelajaran dapat membantu guru untuk mengarahkan peserta didiknya menemukan konsep-konsep melalui aktivitasnya sendiri. 
LKPD menjadi panduan peserta didik dalam mencari pemecahan masalah sesuai dengan indikator yang akan dicapai dalam setiap kompetensi dasar. LKPD disusun oleh guru yang berisikan petunjuk ataupun langkah-langkah penyelesaian yang dapat membantu peserta didik menemukan penyelesaian dari tugas yang diberikan guru.

Oleh karena itu, rumusan masalah penelitian ini adalah: Apakah melalui model pembelajaran discovery learning berbantuan LKPD dalam pembelajaran matematika dapat meningkatkan hasil belajar peserta didik di kelas VIII A UPTD SMPN 9 Marusu Kabupaten Maros? Berdasarkan rumusan masalah tersebut, selanjutnya dirumuskan hipotesis tindakan yaitu: Jika pelaksanaan pembelajaran matematika menerapkan model pembelajaran discovery learning berbantuan LKPD maka hasil belajar peserta didik kelas VIII A UPTD SMPN 9 Marusu Kabupaten Maros dapat meningkat.

\section{Metode Penelitian}

Penelitian ini adalah penelitian tindakan kelas (Classroom Action Research) dengan tahapan yang meliputi perencanaan, pelaksanaan tindakan, observasi dan evaluasi, dan refleksi. Subjek penelitian adalah peserta didik kelas VIII A UPTD Satuan Pendidikan SMPN 9 Marusu Kabupaten Maros pada semester genap 2018/2019 sebanyak 26 orang. Penelitian ini bersifat kajian tindakan kelas, tindakan berupa pelaksanaan proses pembelajaran dengan menggunakan model pembelajaran discovery learning berbantuan LKPD. Dalam penelitian ini peserta didik mengonstruksi pengetahuannya sendiri untuk menemukan dan menyelesaikan LKPD dengan arahan dan bimbingan guru. Hal ini dilakukan agar peserta didik dapat mengurangi kesulitan belajar matematika yang sering dihadapinya. Penelitian dilaksanakan selama dua siklus. Kedua siklus merupakan rangkaian kegiatan yang saling berkaitan, artinya pelaksanaan siklus II merupakan lanjutan dari siklus I.

Siklus I dan siklus II masing-masing berlangsung selama tiga kali pertemuan. Untuk mengetahui jumlah peserta didik yang mengalami kesulitan belajar maka diberikan tes awal yang berfungsi sebagai evaluasi awal. Sedangkan observasi awal digunakan untuk mengetahui tindakan yang tepat yang diberikan dalam rangka meningkatkan hasil belajar peserta didik. Dari evaluasi dan observasi awal maka dalam refleksi ditetapkan bahwa tindakan yang dipergunakan untuk meningkatkan hasil belajar matematika adalah pembelajaran discovery learning.

Jenis data yang diperoleh dari sumber data berupa data kuantitatif yang terdiri dari hasil belajar dan data kualitatif dari hasil pengamatan/observasi. Data yang terkumpul dianalisis secara kuantitatif dan kualitatif. Data hasil pengamatan/observasi dan catatan harian guru dianalisis secara kualitatif, sedangkan data mengenai tes hasil belajar matematika peserta didik dianalisis secara kuantitatif. Menurut Erman (2003) mengemukakan bahwa skor standar yang umum digunakan adalah skala lima yaitu suatu pembagian tingkatan yang terbagi atas lima yaitu: (1) Untuk tingkat $0 \%$ - 39\% dikategorikan sangat rendah, (2) Untuk tingkat $40 \%-54 \%$ dikategorikan rendah, (3) Untuk tingkat 55\% - 74\% dikategorikan sedang, (4) Untuk tingkat $75 \%$ - 89\% dikategorikan tinggi, dan (5) Untuk tingkat 90\% - 100\% dikategorikan sangat tinggi. Indikator keberhasilan penelitian tindakan kelas ini adalah adanya peningkatan skor 
rata-rata hasil belajar peserta didik kelas VIII A UPTD Satuan Pendidikan SMPN 9 Marusu setelah menerapkan model pembelajaran discovery learning berbantuan LKPD.

\section{Hasil Penelitian dan Pembahasan}

\subsection{Hasil Penelitian}

\subsubsection{Pelaksanaan Tindakan Siklus I}

Pelaksanaan tindakan dilakukan melalui tahap perencanaan, pelaksanaan, observasi dan refleksi. Pada tahap perencanaan peneliti bersama kolaborator membuat Rancangan Pembelajaran (RPP) dengan model pembelajaran discovery learning, menyiapkan Lembar Kegiatan Peserta Didik (LKPD) dan membuat lembar observasi untuk mengamati aktivitas peserta didik dalam proses pembelajaran serta lembar soal untuk mengukur tingkat penguasaan materi pembelajaran bangun ruang sisi datar.

Tahap pembelajaran pada siklus I dilaksanakan dengan mengelompokkan peserta didik kedalam empat kelompok yang terdiri atas 6-7 peserta didik setiap kelompok kemudian melaksanakan pembelajaran berdasarkan model pembelajaran discovery learning. Pada tahap stimulasi/pemberian rangsangan, peserta didik melakukan pengamatan dari gambar/foto yang ditampilkan oleh guru, selanjutnya peserta didik melakukan identifikasi masalah dengan membuat beberapa pertanyaan. Dengan bantuan LKPD peserta didik melakukan percobaan untuk mengeksplor pengetahuannya dan melakukan pengumpulan data untuk menemukan penyelesaikan masalah yang diberikan. Peserta didik mengolah informasi yang telah dikumpulkan dengan bantuan langkah-langkah/petunjuk yang diberikan dalam LKPD. Tahap selanjutnya dalam model pembelajaran discovery learning adalah pembuktian, dimana peserta didik mempresentasikan hasil temuan kelompok mereka lalu peserta didik bersama guru bersama-sama menarik kesimpulan dari hasil pembelajaran. Selama kegiatan pembelajaran berlangsung, observasi dilakukan dengan mengamati keseluruhan aktvitas peserta didik dengan mengisi lembar observasi.

Deskripsi statistik menunjukkan hasil belajar peserta didik memiliki skor tertinggi 80 dari skor ideal 100, skor terendah 30, nilai rata-rata sebesar 61,92, dan standar deviasi 12,66. Hasil analisis distribusi frekuensi dan persentase hasil belajar peserta didik sedang. Hal ini karena terdapat 13 orang atau 50,00 \% berada pada kategori sedang yang merupakan persentase tertinggi dari kategori lainnya yaitu sebanyak 5 atau sebesar $19,23 \%$ peserta didik berada pada kategori tinggi, 7 atau sebanyak $26,92 \%$ peserta didik berada pada kategori rendah dan masih ada 1 atau 3,85\% peserta didik yang berada pada kategori sangat rendah. Hasil observasi pada siklus I dari 26 peserta didik, peserta didik yang bertanya tentang materi pelajaran yang kurang dimengerti sebanyak 14,10\%; Peserta didik yang meminta untuk dibimbing oleh guru dalam mengajar soal latihan sebanyak 32,05\%; Peserta didik yang aktif dalam mengumpulkan informasi yang sesuai untuk mendapatkan penjelasan dan pemecahan masalah mencapai $53.85 \%$; Peserta didik yang mengajukan diri untuk mengerjakan soal-soal di papan tulis secara benar adalah 23,08\%; peserta didik yang aktif bekerja sama mengembangkan keterampilan sosial dan keterampilan berpikirnya untuk menyelesaikan masalah/tugas yang diberikan mencapai 75,64\% dan Peserta didik yang melakukan aktivitas lain dalam kelas sebanyak $10,26 \%$. 
Hasil observasi peserta didik pada siklus I diperoleh bahwa dari 26 peserta didik, peserta didik yang bertanya tentang materi pelajaran yang kurang dimengerti sebanyak $14,10 \%$, peserta didik yang meminta untuk dibimbing oleh guru dalam mengerjakan soal latihan sebanyak $32,05 \%$, peserta didik yang aktif dalam mengumpulkan informasi yang sesuai untuk mendapatkan penjelasan dan pemecahan masalah mencapai $53.85 \%$, peserta didik yang mengajukan diri untuk mengerjakan soal-soal di papan tulis secara benar adalah 23,08\%, peserta didik yang aktif bekerja sama mengembangkan keterampilan sosial dan keterampilan berpikirnya untuk menyelesaikan masalah/tugas yang diberikan mencapai 75,64\% dan peserta didik yang melakukan aktivitas lain dalam kelas sebanyak 10,26\%.

Proses dan hasil pembelajaran pada siklus I, sebanyak tiga pertemuan menunjukkan bahwa aktivitas belajar peserta didik secara keseluruhan belum sesuai dengan tahapan dan target model pembelajaran discovery learning. Peserta didik masih memiliki kesulitan dalam pembelajaran seperti dalam pengumpulan data yang mencari informasi dari buku pegangan maupun dari referensi lain dan dalam memahami lembar kerja. Selain itu hasil observasi dilapangan terhadap kemampuan kerjasama peserta didik dalam kelompok untuk menyelesaikan permasalahan masih rendah. Masih terdapat peserta didik yang tidak terlibat dalam kerja kelompok karena tidak peduli dan merasa bahwa kontribusinya tidak dibutuhkan.

\subsubsection{Pelaksanaan Tindakan Siklus II}

Perencanaan tindakan pada siklus II pada dasarnya sama dengan siklus I. berdasarkan hasil refleksi pada siklus I yaitu pada tahapan pengumpulan data, agar peserta didik lebih memahami LKPD, maka peserta didik diberikan informasi tambahan atau referensi lain, agar peserta didik dapat lebih aktif bekerjasama dan saling mendukung dalam bekerja kelompok, maka peserta didik dikelompokkan kembali kedalam 5 kelompok yang terdiri dari 5-6 peserta didik sehingga proses penemuan pemecahan masalah dapat maksimal dilakukan oleh peserta didik.

Hasil tes pada siklus ini menunjukkan skor perolehan tertinggi sebesar 90 dari skor ideal 100, skor terendah sebesar 50, rata-rata sebesar 75,38 dengan nilai standar deviasi sebesar 9,48. Hasil analisis distribusi frekuensi dan persentase hasil belajar peserta didik tinggi. Hal ini karena terdapat 17 orang atau sebesar $65,39 \%$ yang berada pada kategori tinggi merupakan persentase tertinggi dari kategori lainnya. Enam orang peserta didik atau sebesar 23,07\% yang berada pada kategori sedang, hanya 1 orang berada pada kategori sangat tinggi atau sebesar $3,85 \%$, dan 2 orang peserta didik masih berada pada kategori rendah atau sebesar 7,69\%. Serta tidak ada lagi peserta didik yang berada pada kategori sangat rendah. Data ini menunjukkan bahwa telah terjadi peningkatan signifikan hasil belajar peserta didik pada siklus II.

Hasil observasi peserta didik pada siklus II diperoleh dari 26 peserta didik, peserta didik yang bertanya tentang materi pelajaran yang kurang dimengerti sebanyak $25,64 \%$, peserta didik yang meminta untuk dibimbing oleh guru dalam mengajar soal latihan sebanyak 69,23\%, peserta didik yang aktif dalam mengumpulkan informasi yang sesuai untuk mendapatkan penjelasan dan pemecahan masalah mencapai $82,05 \%$, peserta didik yang mengajukan diri untuk mengerjakan soal-soal di papan tulis secara benar adalah $52,56 \%$, peserta didik yang aktif bekerja sama mengembangkan keterampilan sosial dan keterampilan berpikirnya untuk 
menyelesaikan masalah/tugas yang diberikan mencapai $83,33 \%$ dan peserta didik yang melakukan aktivitas lain dalam kelas sebanyak $5,13 \%$.

Temuan ini dipengaruhi oleh peningkatan aktivitas peserta didik dalam model pembelajaran discovery learning berbantuan LKPD. Aktivitas guru dalam mendorong peserta didik pada kelompok masing-masing untuk mencari penemuan pemecahan masalah semakin ditingkatkan. Demikian pula pada aktivitas peserta didik dalam melakukan aktivitas pengumpulan data mengalami peningkatan. Secara umum dapat dikatakan bahwa terdapat peningkatan aktivitas peserta didik kearah yang lebih baik pada siklus II.

\subsection{Pembahasan}

Temuan penelitian menunjukkan bahwa melalui model pembelajaran discovery learning berbantuan LKPD dapat meningkatkan hasil belajar matematika peserta didik Kelas VIII A UPTD Satuan Pendidikan SMPN 9 Marusu yang memenuhi hipotesis tindakan yang diajukan sebelumnya. Dari hasil analisis data deskriptif pada hasil penelitian menunjukkan bahwa setelah pemberian tindakan selama dua siklus, skor rata-rata hasil belajar peserta didik mengalami peningkatan. Pada siklus I skor rata-rata hasil belajar peserta didik yaitu 61,92 yang apabila dikategorikan dalam 5 kategori maka skor tersebut berada pada kategori sedang. Pada siklus II meningkat menjadi 75,38 yang apabila dikategorisasikan ke dalam lima kategori maka skor tersebut berada pada kategori tinggi. Hal ini berarti bahwa pembelajaran matematika dengan menggunakan model pembelajaran discovery learning berbantuan LKPD mengalami peningkatan hasil belajar matematika pada peserta didik Kelas VIII A UPTD Satuan Pendidikan SMPN 9 Marusu sebesar 13,45\%. Secara rinci skor hasil belajar peserta didik dapat dilihat pada tabel perbandingan distribusi frekuensi dan presentase sebagai berikut:

Tabel 1. Tabel Perbandingan Distribusi Frekuensi dan Persentase Skor Hasil Belajar Peserta Didik pada Siklus I dan Siklus II

\begin{tabular}{|c|c|l|c|c|c|c|}
\hline \multirow{2}{*}{ No. } & \multirow{2}{*}{ Skor $(\boldsymbol{*})$} & \multirow{2}{*}{ Kategori } & \multicolumn{2}{|c|}{ Frekuensi } & \multicolumn{2}{c|}{ Persentase } \\
\cline { 4 - 7 } & & & Siklus I & Siklus II & Siklus I & Siklus II \\
\hline 1. & $0-39$ & Sangat rendah & 1 & 0 & 3,85 & 0 \\
2. & $40-54$ & Rendah & 7 & 2 & 26,92 & 7,69 \\
3. & $55-74$ & Sedang & 13 & 6 & 50,00 & 23,07 \\
4. & $75-89$ & Tinggi & 5 & 17 & 19,23 & 65,39 \\
5. & $90-100$ & Sangat tinggi & 0 & 1 & 0 & 3,85 \\
\hline
\end{tabular}

Pada siklus I jumlah peserta didik yang berada pada tingkat penguasaan materi sangat rendah yaitu 3,85\% dan pada siklus II jumlah peserta didik yang berada pada tingkat penguasaan materi sangat rendah yaitu $0 \%$. Pada siklus I tingkat penguasaan materi rendah yaitu $26,92 \%$ dan pada siklus II jumlah peserta didik yang berada pada tingkat penguasaan materi rendah yaitu $7,69 \%$. Pada siklus I tingkat penguasaan materi sedang yaitu $50 \%$ dan pada siklus II jumlah peserta didik yang berada pada tingkat penguasaan materi sedang yaitu 23,07\%, dan pada siklus I jumlah peserta didik yang berada pada tingkat penguasaan materi tinggi yaitu 19,23\% dan pada siklus II jumlah peserta didik yang berada pada tingkat penguasaan materi tinggi yaitu $65,39 \%$. Sedangkan pada kategori tingkat penguasaan materi sangat tinggi, pada siklus I hanya $0 \%$, namun pada siklus II terjadi peningkatan penguasaan materi sebesar 3,85\%. 
Pada siklus I dalam mengerjakan tugas peserta didik masih banyak bekerja secara individu ketimbang bekerja secara kelompok. Peserta didik yang tergolong pintar tidak mau memberitahukan temannya karena mereka beranggapan jika mereka memberi tahu teman akan menjadi bodoh. Jadi hanya peserta didik yang pandai yang memonopoli dan aktif dalam menyelesaikan tugas yang diberikan sedangkan yang lain hanya mencatat tanpa mau berusaha untuk ikut aktif dalam menyelesaikan tugas yang diberikan. Ditemukan pula hanya peserta didik tertentu yang mau mempresentasikan hasil kerja kelompok mereka di depan kelas sedangkan anggota yang lain hanya duduk diam di tempatnya, jadi guru lebih memotivasi peserta didik agar lebih aktif dalam bekerja sama. Membantu peserta didik yang kurang tahu dalam kelompoknya sebab teman kelompoknya kadang-kadang sulit memberitahukannya serta guru secara langsung menunjuk perwakilan dari setiap kelompok.

Dalam proses belajar mengajar peserta didik belum terlalu aktif, hal tersebut terlihat dengan masih banyak peserta didik yang tidak mengerjakan tugas yang diberikan dikelas, ada juga peserta didik yang minta izin keluar kelas dengan alasan buang air kecil. Hal ini disebabkan karena peserta didik belum terbiasa dalam menemukan konsep sendiri dalam menyelesaikan tugas. Untuk memecahkan masalah yang sifatnya kompleks dan diajukan oleh guru/peneliti masih membutuhkan bimbingan. Sehingga keterlibatan guru dalam membimbing dan mengarahkan peserta didik sangat diperlukan untuk meningkatkan keaktifan dan interaksi antara peserta didik serta memotivasi untuk bekerja sama dalam menyelesaikan tugas yang diberikan. Waktu yang digunakan untuk menemukan konsep dan menyelesaikan tugas pada siklus I juga tidak dibatasi, akibatnya peserta didik tidak sepenuhnya terkonsetrasi untuk menemukan penyelesaian masalah sehingga sebagian peserta didik cenderung santai dalam menyelesaikannya.

Pada siklus II penekanan yang diberikan adalah bagaimana peserta didik mampu mengidentifikasi, menemukan dan menyelesaikan soal-soal serta konsep matematika dengan bantuan LKPD agar peserta didik lebih mampu menelaah materi yang diberikan. Pada siklus II, terlihat bahwa sebagian peserta didik telah dapat menyesuaikan diri dengan model pembelajaran discovery learning yang dipergunakan dalam pembelajaran. Hal tersebut terlihat dari persentase jumlah peserta didik yang aktif dalam proses belajar mengajar yang mengalami peningkatan jika dibanding dengan siklus I yaitu banyaknya peserta didik yang mengajukan pertanyaan-pertanyaan untuk materi yang tidak mereka mengerti serta memberikan tanggapan dan komentar saat mereka membahas soal secara bersama-sama. Pada siklus II inipun nampak tingkat penguasaan materi lebih baik, ini terlihat dengan sebagian besar peserta didik sudah langsung menangkap atau memahami materi dengan cepat. Waktu yang digunakan untuk menemukan konsep yang dikerjakan peserta didik pada siklus II juga telah dibatasi. Hal ini berdampak pada peserta didik, sehingga lebih berkonsentrasi dalam menemukan konsep dan menyelesaikan masalah.

Kondisi ini sesuai dengan pendapat Surtikanti dan Santoso (2007) mengungkapkan bahwa pembelajaran yang berkualitas adalah terlibatnya peserta didik secara aktif dalam pembelajaran. Keterlibatan yang dimaksud adalah: aktivitas mendengarkan, komitmen terhadap tugas, mendorong berpartisipasi, menghargai kontribusi/pendapat, menerima tanggungjawab, bertanya kepada pengajar atu teman dan merespon pertanyaan. Secara umum dapat dikatakan bahwa proses belajar mengajar pada siklus II telah mengalami peningkatan 
yang signifikan dibandingkan dengan siklus I. Setelah diberikannya tes akhir siklus II, diperoleh bahwa kemampuan rata-rata peserta didik dalam menyelesaikan soal mengalami peningkatan dibandingkan dengan siklus I, yaitu kemampuan menemukan konsep dalam menyelesaikan soal matematika.

Hasil analisis secara kualitatif menunjukkan bahwa jumlah peserta didik yang bertanya, menjawab pertanyaan, meminta bimbingan guru, dan aktif dalam kelompok terus mengalami peningkatan. Pada siklus I, peserta didik masih membutuhkan bimbingan yang lebih banyak dari guru untuk menemukan hasil akhir dari masalah yang diberikan. Hal ini disebabkan oleh karena peserta didik belum terbiasa dan terlatih dalam menemukan sendiri. Namun demikian, pada siklus II, sebagian besar peserta didik telah dapat memahami dengan baik. Jadi terlihat bahwa secara kuantitatif hasil belajar matematika peserta didik kelas VIII A UPTD Satuan Pendidikan SMPN 9 Marusu mengalami peningkatan dari sedang menjadi tinggi. Demikian pula, secara kualitatif mutu proses belajar matematika peserta didik kelas VIII A UPTD Satuan Pendidikan SMPN 9 Marusu telah mengalami peningkatan dengan menggunakan model pembelajaran discovery learning berbantuan LKPD.

Peningkatan hasil belajar matematika peserta didik kelas VIII A UPTD Satuan Pendidikan SMPN 9 Marusu, secara kualitatif dan secara kuantitatif menunjukkan bahwa model pembelajaran penemuan efektif digunakan dalam pembelajaran. Ini disebabkan oleh karena model pembelajaran discovery learning berbantuan LKPD dapat menumbuhkan motivasi peserta didik untuk belajar matematika. Melalui model pembelajaran discovery learning berbantuan LKPD peserta didik mendapatkan pengalaman menggunakan pengetahuan serta keterampilan yang dimiliki untuk diterapkan pada aspek-aspek kemampuan matematika seperti menemukan konsep/rumus, penerapan aturan pada masalah, menemukan pola, penggeneralisasian, komunikasi matematika, dan lain-lain yang dapat dikembangkan dengan baik.

\section{Kesimpulan dan Saran}

\subsection{Kesimpulan}

Berdasarkan hasil analisis data dan pembahasan yang dikemukakan, maka dapat disimpulkan bahwa penerapan model pembelajaran discovery learning berbantuan LKPD dalam pembelajaran matematika dapat meningkatkan hasil belajar matematika peserta didik kelas VIII UPTD Satuan Pendidikan SMPN 9 Marusu yang indikatornya berupa perolehan skor ratarata hasil belajar matematika peserta didik pada siklus I sebesar $61,92 \%$ meningkat menjadi $75,38 \%$ pada siklus II. Hal ini berarti bahwa pembelajaran matematika dengan menggunakan model pembelajaran discovery learning berbantuan LKPD mengalami peningkatan sebesar $13,45 \%$.

\subsection{Saran}

Berdasarkan hasil penelitan yang diperoleh, maka dalam upaya peningkatan hasil belajar matematika peserta didik, dikemukakan beberapa saran sebagai berikut: 
1. Upaya peningkatan hasil belajar matematika peserta didik kelas VIII UPTD Satuan Pendidikan SMPN 9 Marusu harus dilakukan dengan melibatkan peserta didik dalam proses pembelajaran sehingga muncul kemandirian untuk dapat mengkonstruksi sendiri pengetahuan mereka dalam menemukan konsep atau pola, sehingga pembelajaran dengan model pembelajaran discovery learning berbantuan LKPD merupakan suatu alternatif yang terbaik.

2. Diharapkan kepada para pengajar bidang studi matematika agar memberikan lebih banyak latihan, baik itu berupa latihan yang dikerjakan di sekolah maupun di rumah, dan diharapkan bentuk latihannya berupa penemuan konsep atau rumus yang dapat membantu peserta didik lebih terlatih, lebih mengingat dan memiliki kepercayaan diri dalam menyelesaikan soal-soal matematika.

3. Diharapkan kepada peneliti dalam bidang pendidikan matematika supaya dapat meneliti lebih jauh tentang cara, metode yang efektif dan efisien untuk mengatasi kesulitan peserta didik dalam menyelesaikan soal matematika.

\section{Daftar Pustaka}

Erman Suherman, dkk. 2003. Strategi Pembelajaran Matematika Kontemporer. Bandung: UPI.

Harmin, M. \& Toth, M. 2012. Pembelajaran Aktif Yang Menginspirasi: Buku Pegangan Lengkap Untuk Masa Kini. Jakarta: Permata Puri Media.

Johnson dan Rising. 1972. Math on Call : A Mathematics Hanbook. Great Source Education Group: Inc./Houghton Mifflin Co.

Surtikanti dan Santoso, J. 2007. Strategi Belajar Mengajar. Surakarta: Badan Penerbit-FKIP Universitas Muhammadiyah Surakarta.

Syah. 2004. Psikologi Pendidikan dengan Pendekatan Baru. Bandung: PT Remaja Rosdakarya.

Takdir, I, M. 2012. Pembelajaran Discovery Strategy dan Mental Vocational Skill. Jogjakarta: Diva Press.

Wulandari. 2013. Pengembangan Lembar Kerja Siswa Berbasis Cerita Bergambar Pada Materi Sistem Pencernaan Di SMP. Jurnal Biologi, 8-9. 